\title{
GIÁ TRI LİCH SỦ̉ - VĂN HÓA CÁC DI TÍCH CÔNG XƯỞNG CHẾ TÁC ĐỒ ĐÁ GIAI ĐOẠN ĐÁ MỚI MUỘN Ở TÂY NGUYÊN
}

\author{
Lê Xuân Hưng ${ }^{a^{*}}$
}

${ }^{a}$ Khoa Lịch sủ, Trưòng Đại học Đà Lạt, Lâm Đồng, Việt Nam

*Tác giả liên hệ: Email: hunglx@dlu.edu.vn

Lịch sử bài báo

Nhận ngày 03 tháng 03 năm 2019

Chỉnh sửa ngày 13 tháng 04 năm 2019 | Chấp nhận đăng ngày 25 tháng 04 năm 2019

\section{Tóm tắt}

Nghiên cứu hệ thống các di tích công xuởng chế tác công cu đá ở Tây Nguyên có giá trị đặc biệt quan trọng trong nhận thức văn hoá và lịch sủ một vùng đất. Kết quả của bài viết là quá trình thực địa và nghiên cưu 45 di tích công xuơong chế tác đá. Tu liệu thu được là nguồn sư liệu vật chất minh chưng cho quy trình chế tác một loại hình công cư; Trình độ kỹ thuật, khả năng sáng tạo văn hoá của tùng cộng đồng cu dân cố; Xác định phạm vi phân bố của các loại hình sản phẩm làm ra ở công xuơong và nhận biết đuợc mối quan hệ trao đổi giữa các công xưởng với nhau, với các đơn vị cu trú và những cộng đồng liền kề. Tù nhũng kết quả nghiên cứu trên, bài viết đã đánh giá những giá trị nổi bật của các công xương về các vấn đề: Hệ thống công xương trong giai đoạn hậu kỳ Đá mói - so kỳ Kim khí ở Tây Nguyên; Niên đại và nêu giả thuyểt về chủ nhân của các di tích; Tính thống nhất trong đa dạng của các di tích trong giai đoạn tiền sủ. Đây cũng là kết quả góp phần xác lạp mói các văn hóa khảo cổ, Là cơ sơ để các nhà quản lý đura ra các giải pháp nhằm bảo vệ và phát huy giá trị của các di sản.

Từ khóa: Công xưởng; Đá mới; Phân công lao động; Rìu có vai; Rìu tứ giác.

DOI: http://dx.doi.org/10.37569/DalatUniversity.9.3.551(2019)

Loại bài báo: Bài báo nghiên cứu gốc có bình duyệt

Bản quyền @ 2019 (Các) Tác giả.

Cấp phép: Bài báo này được cấp phép theo CC BY-NC-ND 4.0 


\title{
HISTORICAL - CULTURAL VALUE OF STONE-CRAFTING WORKSHOPS FROM THE LATE NEOLITHIC PERIOD IN THE CENTRAL HIGHLANDS
}

\author{
Le Xuan Hung ${ }^{\mathrm{a}^{*}}$ \\ ${ }^{a}$ The Faculty of History, Dalat University, Lamdong, Vietnam \\ ${ }^{*}$ Corresponding author: Email: hunglx@dlu.edu.vn
}

Article history

Received: March $3^{\text {rd }}, 2019$

Received in revised form: April 13 ${ }^{\text {th }}, 2019 \mid$ Accepted: April 25 ${ }^{\text {th }}, 2019$

\begin{abstract}
Studying the remnants of late neolithic stone-crafting workshops in the Central Highlands plays a particularly important role in understanding this region's culture and prehistory. This article is the result of fieldwork carried out at 45 stone processing sites. The relic materials obtained in the fieldwork demonstrate the process of toolmaking, the technical level, and the ability to create cultural value of each ancient residential community. The diverse relic materials allow us to identify the distribution range of the products made in a factory and recognise the exchange relationships among factories, residential units and neighbouring communities. From the above research results, this article evaluates the outstanding value of the workshops, contributes to a new cultural assessment of the archaeological relics, and provides a scientific basis for administrators to devise solutions to protect and promote this important heritage.
\end{abstract}

Keywords: Ax has a role; Division of labor; New stone; Quadrilateral ax; Workshop.

DOI: http://dx.doi.org/10.37569/DalatUniversity.9.3.551(2019)

Article type: (peer-reviewed) Full-length research article

Copyright @ 2019 The author(s).

Licensing: This article is licensed under a CC BY-NC-ND 4.0 


\section{MỞ ĐẦU}

Theo cách phân kỳ của các nhà khảo cổ học Việt Nam, thời đại Đá mới được chia thành ba giai đoạn: Sơ kỳ, Trung kỳ, và Hậu kỳ (Hà, 1998; Nguyen, 2004, tr. 177188). Giai đoạn sơ kỳ Đá mới, tiêu biểu là văn hoá Hoà Bình - Bắc Sơn. Di tích sớm nhất của văn hóa Hòa Bình là hang Xóm Trại (niên đại khoảng 17,000BP), di tích sớm nhất của văn hóa Bắc Sơn là hang Dơi (niên đại khoảng 11,000BP). Về cơ bản, điểm kết thúc của hai văn hoá này là khoảng 7,000 - 8,000BP. Trung kỳ thời đại Đá mới, tiêu biểu là cư dân các văn hoá Đa Bút, Quỳnh Văn và Cái Bèo. Hậu kỳ thời đại Đá mới ở Việt Nam được ghi nhận với sự xuất hiện một loạt các văn hoá khảo cổ, phân bố trên mọi địa hình của đất nước, như: Văn hoá Mai Pha (Lạng Sơn), Bản Mòn (Sơn La), Hà Giang (Hà Giang - Tuyên Quang), Hạ Long (Quảng Ninh), Bàu Tró (Hà Tĩnh Quảng Bình), Lung Leng (Kon Tum), Biển Hồ (Gia Lai), Buôn Triết (Đắk Lắk)...

Dựa trên hệ thống phân kỳ của khảo cổ học Việt Nam để tham chiếu và xây dựng hệ thống phân kỳ các di tích giai đoạn Đá mới ở Tây Nguyên có thể thấy, ranh giới giữa sơ kỳ và trung kỳ Đá mới chưa thể xác lập một cách rạch ròi, dù ở một số nơi cũng xuất hiện những công cụ tương tự như văn hóa Hoà Bình - Bắc Sơn. Các di tích hậu kỳ Đá mới ở Tây Nguyên cũng chưa thể phân biệt một cách rõ ràng với các di tích thuộc giai đoạn Kim khí nên giới nghiên cứu thường vẫn sử dụng thuật ngữ hậu kỳ Đá mới - sơ kỳ Kim khí để gọi chung cho giai đoạn này. Với tình hình trên, tác giả đồng quan điểm cho rằng, không nhất thiết phải phân chia khảo cổ học giai đoạn Đá mới ở Tây Nguyên thành ba kỳ như vừa trình bày. Trong tình hình tư liệu hiện nay, có thể chia các di tích thời đại Đá mới ở Tây Nguyên thành hai giai đoạn: Thời đại Đá mới sớm (early Neolithic) và thời đại Đá mới muộn (late Neolithic) (Nguyễn, 2007a, tr. 197). Theo đó, thời đại đá mới sớm tương ứng với giai đoạn sơ kỳ và trung kỳ Đá mới; Thời đại Đá mới muộn là tương ứng với giai đoạn hậu kỳ Đá mới - sơ kỳ Kim khí Việt Nam. Sau này, khi tư liệu khảo cổ ở Tây Nguyên tích luỹ được nhiều, chúng ta có thể phân chia các giai đoạn một cách rõ ràng hơn.

\section{CÁC DI TÍCH CÔNG XƯởNG TRONG GIAI ĐOẠN ĐÁ MỚI MUQ̣̂N Ở TÂY NGUYÊN}

Giai đoạn đá mới sớm ở Tây Nguyên được biết đến với những phát hiện về các công cụ cuội mài lưỡi mang dấu ấn Hòa Bình - Bắc Sơn. Chất liệu và kỹ thuật chế tác của nhóm công cụ này là những viên cuội nguyên, không được tạo dáng, người tiền sử chỉ mài vát đều hai mặt tạo phần rìa lưỡi cong lồi và sắc bén. Phần còn lại của viên cuội gần như giữ nguyên lớp vỏ, bên ngoài phủ một lớp phong hóa (patine) dày màu vàng nhạt hay xám tro. Muộn hơn đôi chút là nhóm các di tích ở Thôn Tám (Cư Jút, Đắk Nông), Buôn Kiều (Đắk Lắk), và Làng Gà 4, 5, 6 (Gia Lai) hay các di tích hang động núi lửa ở Krông Nô (Đắk Nông) (Lê, La, Phạm, Vũ, \& Nguyễn, 2018, tr. 57-76). Đặc trưng công cụ của các di tích này là rìu mài lưỡi, công cụ hình bầu dục, và công cụ ghè đẽo, ít rìu ngắn và công cụ hình đĩa.

Nếu như thời đại Đá cũ, ghè đẽo là kỹ thuật độc tôn, bước sang giai đoạn sơ kỳ Đá mới kỹ thuật mài xuất hiện nhưng chỉ mài hạn chế ở rìa lưỡi công cụ. Chuyển sang 
giai đoạn giữa và đặc biệt là hậu kỳ Đá mới, kỹ thuật mài đá trở nên phổ biến, kỹ thuật ghè đẽo đạt đến đỉnh cao. Các kỹ thuật khoan, cưa, đánh bóng lần lượt xuất hiện và ngày càng hoàn thiện. Có thể nói, cư dân tiền sử giai đoạn này đã thuần thục trong việc chế tác các loại công cụ lao động để cho ra đời các sản phẩm có nhiều kiểu dáng khác nhau, vừa mang tính thực dụng nhưng vẫn đảm bảo tính thẩm mỹ cho công cụ. Ở miền Bắc và miền Nam Việt Nam các di tích công xưởng chế tác rìu, bôn đá hoặc công xưởng chế tác vòng tay thường ra đời vào thời đại sơ kỳ Đồng thau. Còn ở Tây Nguyên, loại hình công xưởng chế tác rìu, bôn đá có vị trí quan trọng trong toàn bộ đời sống của cư dân Đá mới muộn. Sự can thiệp sớm với quy mô lớn của các hoạt động công xưởng trong giai đoạn Đá mới muộn là một thành tố quan trọng làm cho lịch sử văn hóa vùng này có nét đặc thù riêng.

Khi nghiên cứu về các loại hình di tích thuộc giai đoạn Đá mới muộn, các nhà khảo cổ học thường chú ý và nhấn mạnh yếu tố ổn định về công cụ đá và đồ gốm. Công cụ chủ đạo ở đây là rìu và bôn đã được mài toàn thân. Ở Tây Nguyên, ngoài các văn hoá đã nhắc đến ở trên, đáng chú ý là đã phát hiện 45 di tích công xưởng chế tác công cụ lao động rìu, bôn... phân bố trên địa bàn các tỉnh Đắk Lắk, Đắk Nông, Gia Lai, và Lâm Đồng. Những di tích này đều thuộc giai đoạn Đá mới muộn, niên đại đoán định khoảng $5,000-3,000 \mathrm{BP}$. Trong đó, di tích công xưởng Thôn Tám và những địa điểm tiền sử khác ở xã Đắk Wil (Đắk Nông), Buôn Kiều (Đắk Lắk), Làng Gà 4,5 và 6 (Gia Lai) là có niên đại cổ xưa hơn cả, niên đại đoán định là trước Đá mới hậu kỳ (Lê \& Nguyễn, 2008, tr. 26; Nguyễn, 2015; \& Phan, 2015). Tuy vậy, ở Thôn Tám và Buôn Kiều đã tìm thấy những mảnh tước có chất liệu đá opal nằm cùng nhóm công cụ rìu hình hạnh nhân, rìu mài lưỡi, đồ gốm rất ít và khá thô - nhóm di vật này rất có thể thuộc giai đoạn Đá mới muộn. Một khó khăn cần lưu ý, việc xếp niên đại cho các di tích công xưởng ở Tây Nguyên chủ yếu là dựa vào đặc trưng hiện vật đá và đồ gốm, ở các công xưởng hoàn toàn chưa xuất hiện đồ đồng hay những dấu vết liên quan đến hoạt động chế tạo đồng. Trong số các di tích này mới có ba địa điểm được phân tích niên đại tuyệt đối bằng phương pháp Carbon phóng xạ $(\mathrm{C} 14)$ và có tuổi: Buôn Kiều $(5,200-5,000 \mathrm{BP})$ (Nguyễn, 2015); Thôn Bốn (4,880BP) và Phúc Hưng (2,890BP) (Lê, 2015, tr. 97).

Một đặc điểm khác, hệ thống các di tích công xưởng ở Tây Nguyên phân bố không đều, tập trung thành các cụm hay các trung tâm với quy mô lớn nhỏ khác nhau. Ở những trung tâm này có nguồn nguyên liệu chế tác khác nhau. Làm ra những sản phẩm không hoàn toàn giống nhau và có phạm vi ảnh hưởng cũng khác nhau. Phải chăng, mỗi di tích công xưởng là một đơn vị cư trú (kiểu một buôn hoặc làng). Thông thường, trong mỗi khu vực ấy có một hoặc vài cụm di tích mà các nhà khảo cổ học gọi là "liên xưởng" như ở Lâm Hà (Lâm Đồng), nhóm di tích ở Ea Kar (Đắk Lắk), nhóm di tích ở xã Ia Mơr, Chư Prông (Gia Lai), nhóm H’lang ở huyện Kong Chro (Gia Lai), hay nhóm Suối Bốn (Đắk Nông). Hoặc, kiểu "liên làng" như ở Kon Tum (Nguyễn, 2007a; Nguyễn, 2007b; Nguyễn, Nguyễn, \& Lê, 2008, tr. 71). Thực tế nghiên cứu cho thấy, những di tích này thường là những đơn vị cư trú kiêm chế tác công cụ đá. Ở những mỏ đá, vừa là nơi khai thác và sơ chế nguyên liệu thành phôi hoặc phác vật thô chưa thật rõ hình (cấp 1), đây là công đoạn đầu tiên. Những phác vật thô, hạch đá được chuyển về nơi cư trú và tiếp tục tu chỉnh và hoàn thiện (cấp 2). Các phác vật đã qua tu chỉnh sẽ được phân 
phối đến các đơn vị cư trú để tiếp tục ghè tu chỉnh ép, cưa, mài... để thành công cụ hoàn thiện (cấp 3), rồi trực tiếp sử dụng và trao đổi với các cộng đồng lân cận hoặc xa hơn.

Sự hình thành một chuỗi các công xưởng chế tác công cụ đá với tính chất, cấp độ khác nhau phản ánh mức độ chuyên hoá và phân công lao động xã hội khá sâu sắc giữa những cộng đồng người liền kề và những cộng đồng cách xa nhau tương đối. Điều ấy có nghĩa, vào giai đoạn Đá mới muộn trong xã hội ở Tây Nguyên đã xuất hiện một nhóm người làm nghề thủ công có tính xã hội hóa, xuất hiện những mối quan hệ trao đổi giữa các bộ tộc. Trong nội bộ cộng đồng, sự phân công lao động theo giới (gender) có lẽ đã diễn ra. Việc chế tác đá đòi hỏi sức mạnh và kỹ năng nhất định nên phù hợp với người nam giới. Các hoạt động nông nghiệp và khai thác thức ăn; Các khâu tu chỉnh hiện vật đá, mài hay nghề thủ công chế tác gốm là công việc nhẹ nhàng hơn sẽ phù hợp với sức lao động của người già, phụ nữ hay trẻ em (Nguyễn \& Lê, 2007, tr. 23). Khi nghiên cứu các công xưởng chế tác công cụ đá trên địa bàn xã Ia Mơr (Chư Prông, Gia Lai), các nhà khai quật đã ghi nhận hiện tượng có nơi tập trung phế liệu thành cụm lớn, có nơi lại ít phế liệu. Chế phẩm hoàn chỉnh ở công xưởng hiếm hoi, chủ yếu là phế vật hay những phác vật bị lỗi kỹ thuật (Nguyễn \& ctg., 2008, tr. 61), hay các địa điểm tiền sử ở Lâm Hà (Lâm Đồng), các địa điểm ở Suối Bốn (Đắk Nông) (Lê, 2011; Lê \& Phan, 2014, tr. 137-139), các di tích ở H'lang - thượng du sông Ba (Gia Lai) cũng ghi nhận hiện tượng trên (Phan, 2015). Phải chăng, đây chính là sự phân công theo nhóm lao động và theo từng tính chất công đoạn của quy trình chế tác công cụ trong các công xưởng ở Tây Nguyên.

Có thể nói, giai đoạn Đá mới muộn ở Tây Nguyên bắt đầu định hướng hoạt động nông nghiệp dùng cuốc. Dùng cuốc trên đất khô và đất phù sa ven sông suối. Số lượng cuốc đá thu được trong nhiều di tích, ở nhiều dạng địa hình khác nhau và cũng rất phong phú về loại hình. Cuốc được sử dụng trong nông nghiệp và gắn với các hoạt động thủ công chế tác đồ đá trong các công xưởng khác nhau. Mặc dù, cuốc tìm thấy trong các công xưởng không nhiều nhưng trong các di tích cư trú giai đoạn tiền sử khác ở Tây Nguyên đã thu được số lượng rất đáng kể. Ngoài cuốc đá, số lượng rìu/bôn trong các công xưởng chiếm số lượng tuyệt đối, góp phần cùng với cuốc đá trong các hoạt động sản xuất nông nghiệp. Về sản phẩm, các di tích công xưởng ở Đắk Lắk thì chuyên chế tạo rìu có vai; Ở Gia Lai chế tác rìu có vai và bôn hình răng trâu; Ở Lâm Đồng chuyên làm rìu tứ giác. Chức năng của các công cụ này có thể là công cụ chặt tre, gỗ làm nhà ở. Phát nương làm rẫy, bới lỗ để tỉa hạt như một loại nông cụ bổ trợ cùng với cuốc đá trong hoạt động nông nghiệp nương rẫy, nông nghiệp dùng cuốc ở nơi đây.

Đến nay, giai đoạn Đá mới muộn ở Tây Nguyên đã ghi nhận có bốn trung tâm lớn chế tác rìu và bôn khác nhau về nguyên liệu, về sản phẩm tạo ra, về quy mô, và tầm ảnh hưởng của chúng giữa các vùng khác nhau của Tây Nguyên (Lê, 2015; Nguyễn, 2010, tr. 3; \& Phan, 2015, tr. 48-59). Đó là các trung tâm: Thôn Bốn - Hoàn Kiếm (Lâm Đồng), trung tâm Ia Mơr - Làng Krông, trung tâm H'lang (Gia Lai), và Chư K'tur - Taipêr (Đắk Lắk - Gia Lai). Ở mỗi trung tâm hay nhóm công xưởng chế tác rìu, bôn đá lại sản xuất ra một loại sản phẩm đặc thù, nguyên liệu chế tác đặc thù có tại địa phương. Ngoài bốn trung tâm kể trên, những tư liệu gần đây cho thấy vào giai đoạn Đá mới muộn ở Tây Nguyên có thể còn có nhóm công xưởng ở Suối Bổn, xã Nhân Đạo 
(Đắk R'lấp, Đắk Nông), nguyên liệu chế tác ở đây gần như tuyệt đối là đá opal (Lê \& Phan, 2013, tr. 137-139). Ở đây chưa tìm thấy các chế phẩm từ công xưởng nhưng trên địa bàn huyện Đắk R'Lấp (Đắk Nông) đã tìm thấy các công cụ rìu vai xuôi và rìu tứ giác dạng gần hình thang bằng đá opal. Rất có thể, đây là những chế phẩm của công xưởng Suối Bốn (Nguyễn \& ctg., 2008; Trần, 2014, tr. 134-137). Kết quả phân loại loại hình mảnh tước ở Suối Bốn cũng cho thấy, có địa điểm nhiều đá nguyên liệu, hạch đá, kích thước mảnh tước lớn, bên ngoài nhiều mảnh còn lưu lại vỏ đá tự nhiên. Có địa điểm mảnh tước kích thước trung bình và nhỏ, ít hạch đá và đá nguyên liệu cũng minh chứng cho quy trình nói trên.

Tựu chung, các di tích công xưởng chế tác công cụ đá ở Tây Nguyên cho thấy tính đặc thù của hoạt động chế tác công cụ. Cùng một lúc xuất hiện các hoạt động chế tác ở nhiều nơi, tạo ra nhiều loại hình sản phẩm. Trong mỗi nhóm cư dân ở một địa hình nhất định lại chế tác ra một hoặc hai loại hình công cụ để sử dụng và trao đổi trong nội bộ cộng đồng và những tộc người liền kề. Sự xuất hiện các công xưởng chuyên hoá đã làm cho các địa phương có sự khác biệt về loại hình công cụ. Những loại hình công cụ đặc trưng ấy đã in đậm lên nội hàm của các văn hoá hoặc các nhóm di tích hiện biết ở Tây Nguyên.

\section{NHẬN THỨC VỀ LỊCH SỬ - VĂN HÓA GIAI ĐOẠN ĐÁ MỚI MUỘN Ở TÂY NGUYŶ̂N}

\subsection{Tạo dụng sự thống nhất trong đa dạng của văn hóa tiền sử Tây Nguyên}

Trong hơn một thập kỷ vừa qua, có ý kiến đã nhấn mạnh đến nền nông nghiệp dùng cuốc ở Tây Nguyên (Nguyễn, 2006, tr. 9-21). Đồng quan điểm trên, chúng tôi cho rằng các nền văn hoá Đá mới muộn ở Tây Nguyên là định hướng nông nghiệp dùng cuốc. Trong các công xưởng cũng như các đơn vị cư trú đã thu được nhiều cuốc đá với nhiều chủng loại khác nhau đã minh chứng cho ý kiến trên. Cuốc không chỉ nhiều về số lượng mà còn phong phú về loại hình. Ở nhiều kiểu địa hình khác nhau đã phát hiện nhiều loại cuốc khác nhau đã cho thấy hoạt động nông nghiệp dùng cuốc hết sức phong phú và đa dạng. Cuốc đá hình răng trâu có số lượng đáng kể nhất ở các di chỉ vùng Bắc Tây Nguyên. Loại cuốc này được làm từ đá phtanite, mài nhẵn toàn thân. Thân cuốc dài, dày và hẹp ngang. Mặt bụng phẳng lõm đều, mặt lưng cong khum có gờ nổi sống giữa, mặt cắt ngang thân gần hình tam giác, chuôi thuôn nhỏ, lưỡi vê cong đều. Loại cuốc này hoàn toàn vắng mặt ở Đắk Lắk, Đắk Nông, và Lâm Đồng. Với loại cuốc có vai, thân hình chữ nhật, kích thước nhỏ, thường làm từ đá silic thì có vai vuông hoặc nhọn, thân mỏng đều, lưỡi rộng, mài nhẵn toàn thân. Loại cuốc này có ở cả Bắc và Nam Tây Nguyên - tập trung nhiều nhất vẫn là các di tích Bắc Tây Nguyên. Nghiên cứu gần đây, trong di tích công xưởng Buôn Kiều (Đắk Lắk), trên bề mặt và ở lớp trên hố khai quật phát hiện được một số phác vật cuốc (Nguyễn, 2015) - đây là ghi nhận đáng chú ý về công xưởng chế tạo cuốc đá ở Tây Nguyên.

Một đặc điểm dễ nhận thấy là trong mỗi địa điểm công xưởng, số lượng phế liệu thải ra từ hoạt động chế tác là rất lớn. Thông thường, hiện vật còn lại ở công xưởng chỉ là phế vật, phác vật công cụ bị lỗi kỹ thuật, mảnh tước chiếm khối lượng đa số. Những 
phác vật hoàn thiện hay rìu mài còn lại ở công xưởng không nhiều. Điều ấy lý giải, phần lớn các sản phẩm từ công xưởng đã được mang đi giao lưu, trao đổi trên địa bàn khá rộng ở Tây Nguyên. Mối liên hệ này được xác định là quan hệ ngoài hệ thống hay ngoài cấu trúc được biểu hiện thông qua quá trình trao đổi sản phẩm, giao lưu văn hoá. Từ nhu cầu trao đổi ngoài hệ thống, đã làm cho một số cộng đồng cư dân xích lại gần nhau hơn. Gắn bó với nhau và hình thành nên các hệ thống liên văn hoá trong một bối cảnh toàn Tây Nguyên. Có thể nói, đây chính là tiền đề cho sự phát triển tương đối đồng đều giữa các vùng. Tạo dựng sự thống nhất trong đa dạng ở giai đoạn Đá mới muộn Tây Nguyên.

Cần nhấn mạnh thêm rằng, với sức sáng tạo văn hoá liên tục, đến giai đoạn Đá mới muộn, cư dân tiền sử Tây Nguyên đã có cuộc "Cách mạng Đá mới" thực sự. Nó được minh chứng bằng sự thay đổi mạnh mẽ từ lối sống không định cư sang định cư. Từ hoạt động săn bắt hái lượm là chủ đạo sang hoạt động làm nông nghiệp và có lẽ các cộng đồng cư dân tiền sử dần mở rộng địa bàn cư trú, tràn xuống các vùng đồng bằng rộng hơn để khai thác nhiều hơn các nguồn lợi từ tự nhiên. Trong ngành nghề thủ công, họ hoàn thiện kỹ thuật chế tác công cụ đá nơi các công xưởng. Nghề làm gốm ra đời và mang những dấu ấn địa phương. Trong một số di tích như Thôn Bốn (Lâm Đồng), Chư K'tur (Đắk Lắk), Taipêr (Gia Lai)... đã phát hiện những dấu vết lỗ chân cột nó minh chứng cư dân tiền sử cư trú ngoài trời, dựng lều bằng tre gỗ để làm nhà ở.

Những hoạt động thủ công còn thúc đẩy việc hình thành các điểm cư trú lâu dài. Bếp là minh chứng hết sức rõ ràng cho cuộc sống định cư của một đơn vị hộ gia đình hoặc đại gia đình. Nhìn chung, bếp thường có quy mô nhỏ, là bếp kiểu gia đình cặp đôi. Nhưng, cũng có bếp quy mô lớn, xếp đá phiến xung quanh, hẳn là bếp tập thể của cộng đồng hay gia đình lớn với nhiều thế hệ. Có những bếp đơn sơ, và tạm bợ (thường thây trong các di tích cư trú - xưởng), lại có những bểp đắp thành lò và chắc chắn được sử dụng lâu dài. Khi nghiên cứu về các di tích tiền sử ở Kon Tum, các nhà khảo cổ đã chỉ ra rằng, ở đây có sự hiện diện của bốn liên làng (Nguyễn, 2007a, tr. 80-84; Nguyễn, 2007b; Nguyễn \& ctg., 2008, tr. 71). Liên làng 1 ở ngã ba sông Krông Pôkô và Đắk Bla với 14 làng cổ; Lung Leng và Jơ Đrợp là hai làng hạt nhân của cụm di tích này. Liên làng 2 ở thị xã Kon Tum với 13 làng cổ, Rừng Keo và Kon K'Lor là hai làng hạt nhân. Liên làng 3 gồm 14 làng cổ ở hai bờ sông Krông Pôkô thuộc vùng núi thấp, xen kẽ các thung lũng hẹp Sa Thầy, Đắk Hà; Bến Tắm, và Đắk Rei là làng hạt nhân. Liên làng 4 với năm làng cổ ở thượng lưu Krông Pôkô, Đắk Mơ Ham, và Thôn Ba là làng hạt nhân. Các cụm di tích, các liên làng nói trên là biểu hiện của sự liên kết cộng đồng theo địa vực và tộc thuộc.

Trong văn hoá tín ngưỡng, cư dân tiền sử biết chăm sóc cho người chết qua việc chôn theo những đồ tuỳ táng. Mộ táng được đặt tại nơi cư trú, trong các di tích công xưởng hay khu mộ táng riêng biệt. Cách táng thức khá đa dạng, có: Mộ đất (huyệt tròn, huyệt dài), mộ kè gốm (kè tròn, kè dài), mộ chum, mộ nồi/ vò úp nhau, và mộ vò. Đồ tuỳ táng chôn theo trong mộ không giống nhau, thường là rìu đá và đồ gốm. Đồ đá chôn theo thường là đồ mới, nguyên vẹn nhất và chưa có dấu vết sử dụng. Đồ gốm chôn theo thường bị đập vỡ trước khi chôn (rất ít đồ nguyên). Có thể, đây là tư duy cho rằng người sống thì dùng đồ lành, người chết thì dùng đồ vỡ. Một vấn đề cần lưu ý là tư duy tâm linh của người tiền sử xuyên suốt qua đồ tuỳ táng là tổng số vật chôn theo luôn là số lẻ: 
1, 3, 5, hoặc 7 (Nguyễn \& ctg., 2008; \& Nguyễn \& Phan, 2007). Có một số mộ chôn theo nhiều hiện vật và có mộ ít, có mộ lại chôn theo công cụ lao động hay những phác vật chưa được mài, có mộ chôn theo vòng đá... Qua tư liệu ấy có thể lý giải là ở đây ít nhiều có sự phân biệt về thân phận, vị thế chủ nhân của ngôi mộ - nó phù hợp với kết cấu làng. Tuy nhiên, mức độ khác biệt ấy có lẽ là không lớn trong giai Đá mới muộn ở Tây Nguyên.

\subsection{Khả năng xác lập văn hoá và vấn đề chủ nhân}

\subsubsection{Khả năng xác lập mới các văn hoá khảo cổ ở Tây Nguyên}

Đến nay, ở Tây nguyên đã xác lập được một số văn hoá khảo cổ ${ }^{1}$. Ngoài những nét chung, các văn hoá này đều có những đặc trưng tạo thành sắc thái riêng và có mối liên hệ chặt chẽ của tiền sử Tây Nguyên. Các văn hoá gồm: Văn hoá Lung Leng (Kon Tum) (Lê \& Nguyễn, 2006, tr. 87-100; Nguyễn, 2005, tr. 84; \& Nguyễn, 2007b); Văn hoá Biển Hồ (Gia Lai) (Lê \& Nguyễn, 2006, tr. 100-110; Nguyễn, 1995, tr. 7-16); và Văn hoá Buôn Triết (Đắk Nông) (Lê \& Nguyễn, 2006, tr. 111-117; Nguyễn, 2007a, tr. 113).

Với sự ra đời của hàng loạt các di tích công xưởng chế tác công cụ đá giai đoạn Đá mới muộn đã cho chúng ta thấy giữa Nam và Bắc Tây Nguyên có mối liên hệ và giao lưu văn hoá chặt chẽ chứ nó không hoàn toàn đóng kín và khác biệt như có ý kiến đã đề cập (Trần, 2001). Đặc biệt, nghiên cứu hệ thống các di tích công xưởng ở từng khu vực còn giúp chúng ta nhìn nhận rõ hơn về các văn hoá khảo cổ đã xác lập. Thêm nữa, đã có giả thuyết đưa ra về khả năng xác lập các văn hoá mới ở Tây Nguyên, như: "Văn hoá Taipêr" (Nguyễn, 2003, tr. 103-112; Nguyễn, 2014, tr. 635; \& Nguyễn, $2007 b$, tr. 29). Nội hàm của văn hoá này là các di tích công xưởng, di tích cư trú xưởng hay cư trú có đặc trưng hiện vật đá và gốm giống nhau, địa vực phân bố của các di tích này liền khoảnh. Văn hoá Taipêr có trên 20 địa điểm, phân bố ở huyện Chư Sê, Chư Prông, Chư Pứ... (Gia Lai), Ea H'leo, và Ea Kar (Đắk Lắk). Trong đó, di tích Taipêr và $C h u ̛$ K'tur là hai mắt xích quan trọng, chuyên chế tác rìu và bôn vai xuôi. Nguyên liệu chế tác chủ yếu là đá silic và opal.

Trong văn hoá Taipêr, mỗi di tích có đặc điểm cư trú và một quy trình chế tác rìu bôn đá không giống nhau. Ví như, các di tích ở Ea Kar (Đắk Lắk) chia thành hai công đoạn chế tác, có di tích khai thác nguyên liệu và sơ chế phôi đá, có di tích tu chỉnh và hoàn thiện phác vật. Ở các di tích này, tầng văn hoá thường không dày lắm, ít than tro và rất ít mảnh gốm đã phản ánh yếu tố công xưởng đậm nét, yếu tố cư trú mờ nhạt và mang tính tạm thời. Trong khi đó, ở di tích Taipêr, Làng Ngol, Đồng Hải (Gia Lai)... tầng văn hoá dày, có bếp, mộ táng và rất nhiều đồ gốm. Phác vật thu được là rìu có vai hoàn thiện, rìu bôn mài và nhiều chiếc có vết sử dụng. Vết tích cư trú khá đậm nét, đó là sự xuất hiện của rìu mài toàn thân, có vết sử dụng, công cụ mảnh tước, bàn mài, chày, hòn ghè... nhiều. Nhìn chung, nhóm di tích Thanh Sơn, Bản Thái, Chư K'tur, Tsham A;

${ }^{1}$ Là di tích hay nhóm các di tích có cùng chung: Đặc trưng di tích, di vật; Tính chất; Niên đại và chủ nhân; Phạm vi phân bố liền khoảnh được gọi là "Văn hóa khảo cổ". 
Taipêr, Làng Ngol, Làng Cùi, Làng Ngol, Đồng Hải, Plei Kriêng... có đặc trưng là sự phổ biến rìu bôn có vai (Hình $1 \mathrm{a}$ ), kích thước nhỏ, hiếm rìu bôn tứ giác và bôn răng trâu. Nguyên liệu chế tác chủ đạo là đá sét silic và opal. Tồn tại gốm thô màu nâu đỏ, nhiều gốm văn thừng, văn chải, và văn in chấm. Những đặc trưng này phân biệt với văn hoá Biển Hồ, văn hoá Lung Leng ở phía bắc và văn hoá Buôn Triết ở phía Nam Tây Nguyên. Đây chính là một trong những cơ sở quan trọng để xác lập một văn hoá khảo cổ mới - "Văn hoá Taipêr". Chính văn hóa Taipêr đã góp phần tạo nên sự thống nhất trong đa dạng của Tiền sử Tây Nguyên (Nguyễn, 2004a, tr. 28; Nguyễn, 2006, tr. 9; Nguyễn, 2007a, tr. 104; \& Nguyễn, 2007b, tr. 29).

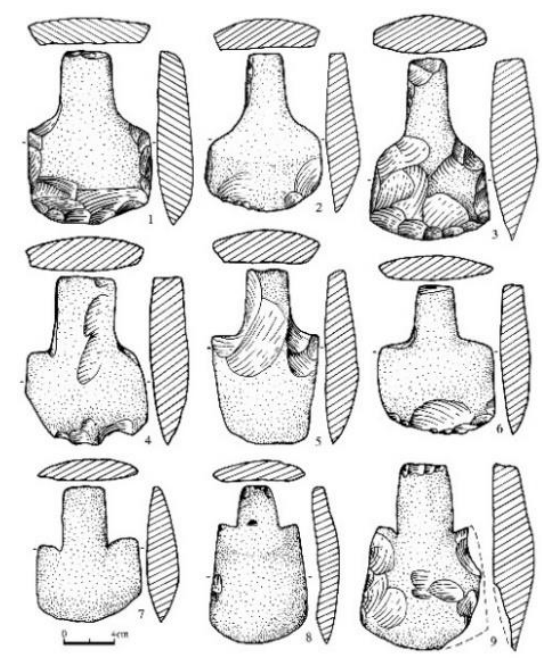

(a)
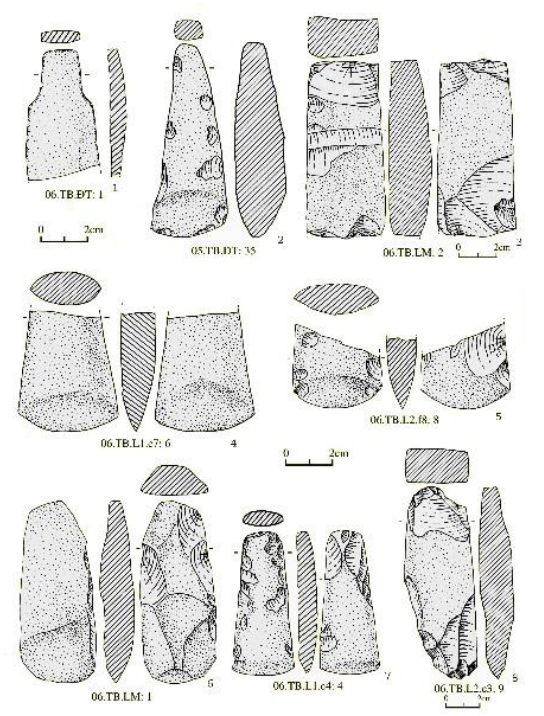

(c)

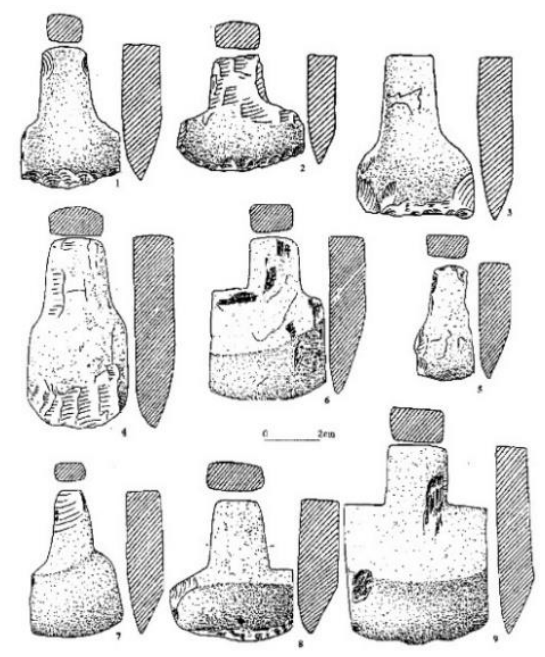

(b)

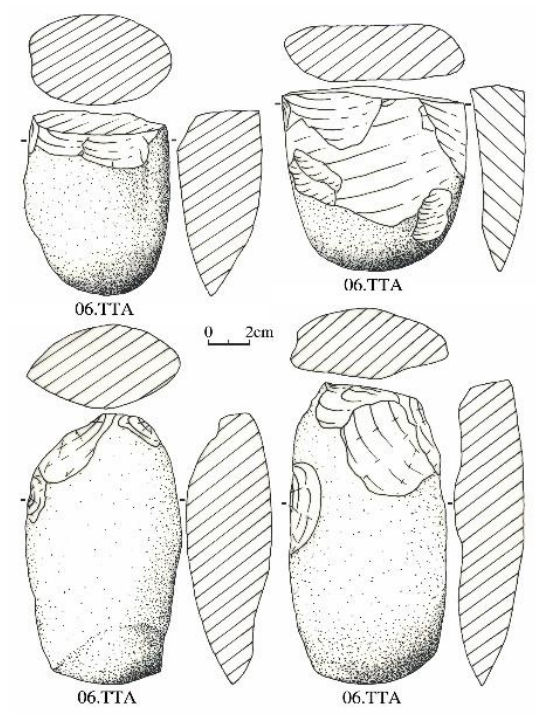

(d)

Hình 1. Công cụ đá trong các di tích ở Tây Nguyên

Ghi chú: a) Rìu bôn có vai di tích Taipêr; b) Đồ đá di tích Biển Hồ; c) Rìu mài di tích Thôn Bốn, khai quật năm 2006; và d) Rìu mài lưỡi di tích Thôn Tám A, khai quật năm 2006

Nguồn: Lê (2015). 
Trên cao nguyên Buôn Ma Thuột có thể xác lập "Văn hóa Buôn Ma Thuột" (Nguyễn, 2014, tr. 636; Nguyễn, 2004a, tr. 122; \& Nguyễn, 2007a, tr. 121). Văn hoá này có hơn 10 di tích, trong đó tiêu biểu là địa điểm Dhap Rông, Thôn $\mathrm{Ba}$, Cao Thắng, Ea Tiêu (TP. Buôn Ma Thuột), Ea Gar, Chư Păh (Ea Kar), Buôn Râu (Krông Păk), Thôn Một, Cư Suê, (Chư M'nga), Thôn Một, và Thôn Mười (Cư Jút, Đắk Nông). Đặc trưng của văn hóa này là phân bố ở cao nguyên Buôn Ma Thuột. Hiện vật chủ yếu là cuốc, rìu, bôn hình thang, một số rìu gần hình bầu dục, hình chữ "U”, hình tam giác và đều được làm từ đá basalt. Vắng mặt hoàn toàn bôn hình răng trâu, rìu có vai làm từ đá opal hay silic.

Đồ gốm ở văn hoá này khá đa dạng, phong phú với các kiểu dáng, như: Bát bồng chân cao, bát chân đế thấp loe choãi, và nồi gốm với nhiều kích cỡ khác nhau. Có nồi thân hình cầu, nồi thân gãy góc, vò, chậu có chân đế... Loại hình miệng có: Loe ưỡn, loe thẳng, miệng khum... Về chất liệu, gốm chủ yếu làm từ loại đất sét pha cát, pha bã thực vật với kích cỡ trung bình. Gốm xốp và nhẹ, độ nung không cao, lớp áo gốm dễ bị bong tróc. Xương gốm có các loại: Xương nâu đỏ, xám vàng, xám đen và xám nhạt. Về kỹ thuật, gốm được nặn bằng tay, dải cuộn, kết hợp với bàn đập hòn kê và miết láng bề mặt. Hoa văn trang trí chủ yếu là văn khắc vạch đơn và văn in chấm. Nhìn chung, cư dân tiền sử nơi đây sống định cư, làm nông nghiệp và có quan hệ gần gũi với cư dân văn hóa Buôn Triết (Nguyễn, 2007a, tr. 122). Văn hóa Buôn Ma Thuột có những đặc trưng khác với văn hoá Buôn Triết và văn hoá Taipêr.

Một khái niệm văn hoá khác cũng được đưa ra là "Văn hoá Lâm Hà" (Lê, 2011, tr. 20; \& Lê, 2015; \& Trần, 2014, tr. 214). Văn hoá này có hơn 10 địa điểm phát hiện trên địa bàn huyện Lâm Hà (Lâm Đồng). Đặc trưng của nhóm công cụ là chế tạo rìu, cuốc tứ giác có kích thước trung bình và nhỏ (Hình $1 \mathrm{c}$ ). Đốc rìu nhỏ hơn phần lưỡi không nhiều, mặt cắt ngang và dọc thường có hình elip, chất liệu chế tác gần như tuyệt đối là đá opal. Những đặc điểm này khác với các di tích công xưởng ở Bắc Tây Nguyên chuyên chế tác và sử dụng bôn răng trâu và rìu vai xuôi hay các di tích ở Đắk Lắk là rìu vai ngang, ít rìu tứ giác, nguyên liệu chế tác chủ yếu là đá opal, ở Đắk Nông là rìu hình bầu dục (Hình 1d), nguyên liệu chế tác là đá basalte, silic... Đồ gốm ở các di tích không nhiều và đều là gốm thô, bở. Chất liệu chế tạo là đất sét pha nhiều cát và bã thực vật. Gốm không được miết láng, không có hoa văn, mềm và dễ thấm nước, phần lớn các mảnh đều đã bị bong mất lớp áo bên ngoài. Thành gốm tương đối mỏng, mặt ngoài thường có màu xám. Kỹ thuật làm gốm bằng bàn xoay, những mảnh gốm vỡ ra từ các đồ gia dụng. Nhìn chung, đồ gốm ở văn hoá này có hai loại: Loại thứ nhất là gốm màu xám đen, pha ít bã thực vật và nhiều cát, áo gốm màu đỏ nhạt gần với gốm di chỉ Đắk R'lấp (Đắk Nông). Loại thứ hai là gốm màu đỏ nhạt, pha cát và nhiều bã thực vật lớp áo gốm màu đỏ nhạt.

Ngoài ra, còn có thể xác lập "Văn hoá Thôn Tám”, gồm di chỉ Thôn Tám và các địa điểm ở đầm Sương Mù, Thôn Bảy, xã Đắk Wil, huyện Cư Jút (Đắk Nông), nhóm di tích công xưởng ở Buôn Kiều (Đắk Lắk) và nhóm di tích ở Làng Gà (Gia Lai). Đây là các di tích đại diện cho giai đoạn Đá mới giữa và bắt đầu chuyển sang giai đoạn hậu kỳ Đá mới ở Tây Nguyên (Lê \& Nguyễn, 2006, tr. 18-29; Lê, 2013; \& Lê, 2015). 


\subsubsection{Giả thuyết về chủ nhân của các văn hoá tiền sủ ở Tây Nguyên}

Ngoài những vấn đề nêu trên, nghiên cứu công xưởng chế tác công cụ đá ở Tây Nguyên còn góp phần nhận thức một số vấn đề khảo cổ học lý thuyết đã và đang đặt ra trong nhiều thập kỷ qua. Geldern (1932, tr. 543) đưa ra lý thuyết gắn mỗi loại rìu đá với một văn hóa riêng, và một ngôn ngữ - tộc người riêng. Ống chia thời đại Đá mới ở Đông Nam Á thành các văn hóa rìu có vai, rìu tứ giác, và rìu bầu dục. Theo Geldern (1932), chủ nhân văn hóa rìu có vai, người sử dụng là ngữ hệ Nam Á (Austro-Asiatique) trong đó có nhóm Môn-Khmer và Munda, thuộc đại chủng Mogoloide. Văn hóa rìu tứ giác gắn với người Nam Đảo (Malayo-Polynesien) nguồn gốc từ vùng Tây Nam Trung Quốc, vào khoảng 4,000BP, họ tràn xuống Đông Dương qua Tứ Xuyên và Vân Nam hình thành văn hóa hỗn hợp giữa văn hóa rìu có vai và văn hóa rìu tứ giác. Lafont (1956) dựa vào đây để giải thích rằng người dùng rìu tứ giác nói ngôn ngữ Malayo-Polynesien đến trước, còn người dùng rìu có vai, nói ngôn ngữ Môn-Khmer đến sau, rất muộn sau này, bởi rìu tứ giác rất ít ở cao nguyên Pleiku (Lafont, 1956, tr. 237). Lafont cho rằng, rìu tứ giác có số lượng ít hơn rìu có vai, chứng tỏ trong thời đại Đá mới những người truyền bá văn hóa rìu có vai (Schulterbei Kultur) quan hệ rất muộn với các đại diện của văn hóa rìu tứ giác ở đây (Lafont, 1956, tr. 233-248). Khi nghiên cứu tiền sử Tây Nguyên, các nhà khảo cổ học Việt Nam đã bác bỏ lý thuyết trên (Lê, 2015; \& Nguyễn, 2007a, tr. 281). Bởi vì, vào cùng một thời điểm Đá mới muộn, ở Tây Nguyên đã xuất hiện bốn trung tâm và các nhóm công xưởng chế tác công cụ với ba loại hình rìu, bôn đá khác nhau. Mỗi loại công cụ phù hợp giữa hình dáng, kích thước, chất liệu với từng tiểu vùng địa lý. Các trung tâm này có mối liên hệ với nhau và là nhân tố quan trọng tạo nên sự thống nhất trong đa dạng của tiền sử Tây Nguyên. Từ những dẫn liệu trên, căn cứ vào bản đồ phân bổ ngôn ngữ tộc người ở Tây Nguyên (Hình 2) có thể đưa ra giả thuyết:

- Chủ nhân văn hoá Biển Hồ: Văn hoá này hiện biết hơn 30 địa điểm có cùng niên đại, đặc trưng của hiện vật đá và gốm, địa vực liền kề và phân bố tập trung trên cao nguyên Pleiku (Gia Lai). Cư dân tiền sử Biển Hồ sử dụng phổ biến bôn hình răng trâu làm từ phtanite, rìu, và bôn có vai làm từ đá silic và opal (Hình $1 \mathrm{~b}$ ). Kích thước của những công cụ thường nhỏ nhắn, được mài toàn thân. Những rìu và bôn bị hỏng trong quá trình sử dụng được ghè lại lưỡi tạo thành công cụ mũi nhọn, những viên đá gia trọng thân hình bánh xe có lồ thủng giữa. Đồ gốm là đất sét pha cát, nặn tay tạo ra nồi, bát bồng, vò, ấm có vòi... (Nguyễn, 1995; Lê \& Nguyễn, 2008).

Đặng và Cẩm (1981) khi nghiên cứu về các tộc người tại chỗ ở Bắc Tây Nguyên đã cho rằng, lớp cư dân đầu tiên cư trú ở địa bàn Gia Lai và Kom Tum là những người lùn, đen thuộc đại chủng Australoid nay không còn nữa. Những người nói ngôn ngữ Môn-Khmer, tổ tiên trực tiếp của đa phần cư dân thuộc nhánh ngôn ngữ Bahnar bắc hiện nay đã có mặt ở đây ít nhất từ thời đại đá. Tiếp đến, tổ tiên những người nói tiếng Malayo-Polynesien từ ven biển tiến lên, tách các cư dân Môn-Khmer thành hai bộ phận. Sự phân chia đó diễn ra cách đây khoảng 2,000 - 3,000BP (Đặng \& Cẩm, 1981, tr. 22). 


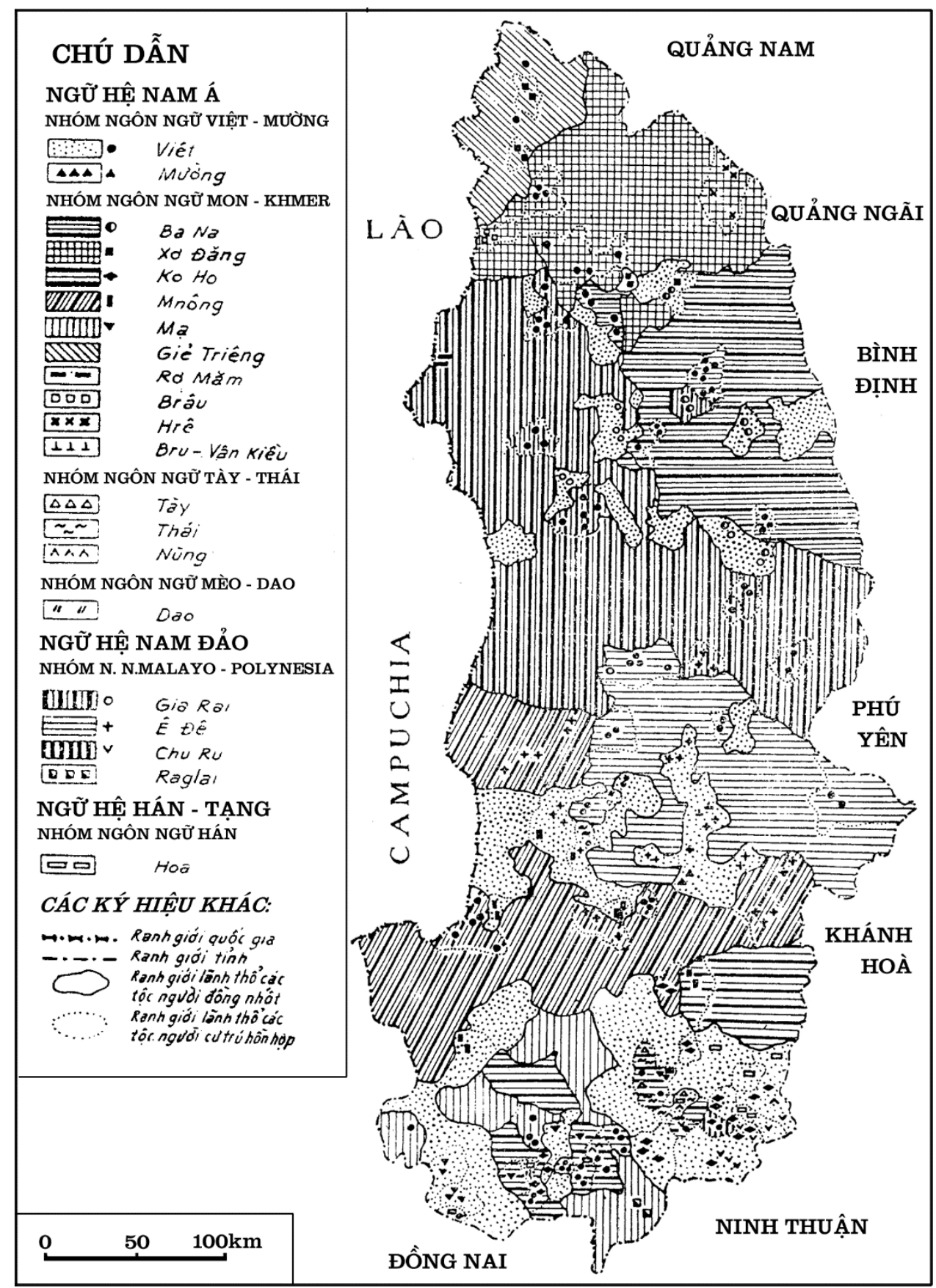

Hình 2. Phân bố ngôn ngữ và tộc người ở Tây Nguyên

Nguồn: Dẫn lại theo Lê (2015).

Trong chuyên khảo Tiền sủ Gia Lai các tác giả cũng cho rằng, chủ nhân của văn hóa Biển Hồ là cư dân nói ngôn ngữ Nam Đảo (Malayo-Polynesien) (Vũ, 1995). Một nghiên cứu khác cũng tán thành với giả thuyết trên và cho rằng, vào giai đoạn Đá mới muộn tổ tiên của người Jrai đã có mặt trên cao nguyên Pleiku và trở thành chủ nhân của văn hóa Biển Hồ (Nguyễn, 2004, tr. 927). 
Qua phân tích loại hình di vật phân bố trong địa tầng ở một số di tích Biển Hồ, Trà Dôm, Thôn Bảy, Taipêr, Làng Ngol... chúng tôi đồng quan điểm với ý kiến ở khu vực Bắc Tây Nguyên trong thời đại Đá mới, những cư dân sử dụng rìu có vai xuất hiện trước những người sử dụng rìu tứ giác (Nguyễn, 2007a, tr. 281; Lê, 2015). Và theo đó, nếu mỗi loại rìu gắn với một thứ ngôn ngữ tộc người nhất định là đúng, thì ở Bắc Tây Nguyên trong thời đại Đá mới, cư dân nói ngôn ngữ Nam Á có mặt trước cư dân nói ngôn ngữ Nam Đảo. Theo bản đồ phân bố tộc người ở Tây Nguyên, nhóm Jrai Hdrung cư trú quanh thành phố Pleiku và trên cao nguyên Pleiku. Về cơ bản là trùng khớp với phạm vi phân bố của văn hoá Biển Hồ. Nhóm Jrai Chor cư trú ở vùng đồng bằng thung lũng sông $\mathrm{Ba}$, sông Ayun và các huyện Chư Sê, Chư Pứ (Gia Lai), Ea Kar, Ea H'leo, Ea Súp (Đắk Lắk), ở đây là địa bàn phân bố của một số các di tích khảo cổ như Chư K'tur, Thanh Sơn, Bản Thái, Taipêr... Có ý kiến đã cho rằng, có thể chủ nhân văn hóa Biển Hồ là nhóm Jrai Hdrung (Nguyễn, 2007a, tr. 104).

- Chủ nhân văn hóa Lung Leng: Phân bố chủ yếu ở vùng núi thấp Sa Thầy và vùng trũng Kon Tum. Đến nay, văn hoá này đã phát hiện và nghiên cứu trên 50 di tích. Các di tích ở đây có đặc điểm chung là cư trú ngoài trời, cạnh các sông lớn, sử dụng phổ biến cuốc đá có vai vuông chế tác từ đá silic, opal. Bôn hình răng trâu được làm từ đá sét silic. Rìu vai xuôi, vai vuông, vai nhọn làm từ đá silic hay đá opal. Đồ gốm gia dụng trong văn hoá Lung Leng thường có kích thước nhỏ và trang trí hoa văn đẹp. Những đồ gốm lớn thì thường làm quan tài chôn người chết, đồ gốm tùy táng nặn tay, tô thổ hoàng hoặc tô đen ánh chì. Cư dân văn hoá Lung Leng là những người có lối sống định cư và làm nông nghiệp (Nguyễn, 2007a, tr. 55-56; Nguyễn, 2007b).

Kết quả khai quật và nghiên cứu khảo cổ học cho thấy, vào giai đoạn Đá mới muộn, giữa Bắc và Nam Tây Nguyên có sự khác biệt về việc chế tác và sử dụng rìu và bôn đá. Sự khác biệt ấy còn cho thấy cư dân tiền sử Tây Nguyên cư trú trên những địa bàn nhất định sẽ chế tác ra một loại hình công cụ phù hợp với truyền thống và môi trường canh tác. Mặc dù có những khác biệt về truyền thống chế tác và sử dụng công cụ đá nhưng ở đây vần cho thấy sự tiếp xúc, giao thoa văn hóa của các nhóm tộc người khác nhau. Và có lẽ, sự tiếp xúc và giao thoa này chính là sự tiếp xúc của hai khối cư dân nói ngôn ngữ chính là Nam Á và Nam Đảo. Sự tiếp xúc diễn ra vào các thời điểm khác nhau, trong từng tiểu vùng khác nhau nên cũng tạo ra các đặc trưng văn hóa không giống nhau (Nguyễn, 2013b; Nguyễn, 2014).

Gần đây, một nghiên cứu đáng chú ý về ngôn ngữ tộc người đã chỉ ra rằng, trong các ngôn ngữ Bahnar bắc ở Tây Nguyên chứa đựng nhiều từ vựng có nguồn gốc chung với các ngôn ngữ Nam Á cổ. Nghĩa là, cư dân nói ngôn ngữ thuộc tiểu chi Bahnar ở Tây Nguyên sớm hơn khu vực Duyên hải Miền Trung và nam Đông Dương (Đoàn, 2012). Và có lẽ, lớp cư dân nói ngôn ngữ thuộc tiểu chi Bahnar đầu tiên tương ứng với lớp dưới di chỉ Lung Leng, niên đại ít nhất cách đây hàng vạn năm. Những người nói ngôn ngữ Nam Á tiếp tục cư trú ở Lung Leng và một số di tích tiền sử khác. Họ chế tác và sử dụng công cụ đá mài toàn thân, chế tạo đồ gốm, sau nữa là chế tác và sử dụng công cụ đồ đồng và sắt như đã từng thấy trong các địa điểm khai quật ở Lung Leng hay 
lòng hồ Plêy Krông. Trong quá trình đó, cư dân ở đây bắt đầu tiếp xúc với cư dân nói ngôn ngữ Nam Đảo. Những nhóm người này mang theo truyền thống sử dụng rìu tứ giác, có thể cả bôn hình răng trâu và mộ chum. Di tồn văn hóa của họ còn gặp ở lớp trên di chỉ Lung Leng hoặc các di chỉ trong lòng hồ Plei Krông (Kon Tum) (Nguyễn, 2013a).

Khi cư dân Nam Đảo thuộc chi Chăm lên Bắc Tây Nguyên, tại đây họ đã tiếp xúc với cư dân nói ngôn ngữ chi Bahnar. Vốn từ vựng của cư dân các ngôn ngữ chi Bahnar và chi Chăm còn mang đậm dấu vết của sự tiếp xúc ngôn ngữ này. Sự tiếp xúc của cư dân nói ngôn ngữ Nam Đảo ở khu vực Bắc Tây Nguyên có thể cách đây khoảng 2,500 - 3,500BP (Đoàn, 2012). Giả thuyết về hướng di cư của người nói ngôn ngữ Nam Đảo từ vùng biển Nam Trung Bộ lên Tây Nguyên đã nhận được sự ủng hộ về mặt tư liệu khảo cổ học. Khả năng tiếp xúc văn hóa ngôn ngữ tộc người giữa cư dân nói ngôn ngữ Nam Á và Nam Đảo không chỉ ở Bắc và Nam Tây Nguyên mà nó còn diễn ra cả vùng Duyên hải Trung Bộ lên Bắc Tây Nguyên (Nguyễn, 2013b).

Khi áp bản đồ phân bố các tộc người hiện đại lên bản đồ các văn hóa khảo cổ ở Tây Nguyên có thể thấy, nhóm cư dân nói ngôn ngữ Nam Đảo ở Bắc Tây Nguyên (chủ yếu là người Jrai). Nhóm cư dân này chủ yếu cư trú ở tây nam tỉnh Kon Tum, có thể trùng với phạm vi phân bố rìa phía nam của văn hoá Lung Leng (Nguyễn, 2013b). Vấn đề đặt ra là, chủ nhân văn hóa Lung Leng là tộc người nào: Bahnar, Xơ đăng, Giẻ Triêng của ngữ hệ Nam Á, hay Jrai Arap của ngữ hệ Nam Đảo. Dựa vào kết quả thống kê từ vựng bằng phương pháp ngữ thời học, Đoàn (2012) cho rằng, vào thời đại Đá mới, cách đây chừng 4,500BP, cư dân nói ngôn ngữ tiểu chi Bahnar mới được chia tách. Song, đến giai đoạn Kim khí, khoảng $2,500 \mathrm{BP}$, rất có thể đây là thời điểm xuất hiện cư dân nói các ngôn ngữ Nam Đảo ở Kon Tum.

- Chủ nhân của các nhóm di tích khác: Tư liệu khảo cổ học ở Tây Nguyên và vùng Trung $B \hat{o}$ đã ủng hộ ý kiến cho rằng, nhóm ngốn ngữ Bahnar tách thành Bahnar Bắc và Bahnar Nam vào khoảng thiên niên kỷ III và II trước Công nguyên. Các bộ tộc này phân tán thành nhiều nhóm nhỏ, cư trú ở nhiều nơi trên đất Tây Nguyên, hình thành nên các nhóm phương ngữ, các nhóm văn hóa khảo cổ khác nhau. Chẳng hạn, nhóm di tích Buôn Ma Thuột phân bố trên cao nguyên Đắk Lắk, nơi định cư tập trung và rất lâu đời của người Ê Đê. Nhóm các di tích Buôn Triết với đặc trưng cuốc đá lớn thân hình bầu dục, phân bố quanh Hồ Lắk (Đắk Lắk), là địa bàn cư trú tập trung của người Mnông. Nhóm các di tích Đá mới muộn ở huyện Lâm Hà (Lâm Đồng) với sự tồn tại phổ biến của rìu tứ giác bằng đá opal, là địa bàn cư trú của người Mạ và người Cơ Ho. Những nhóm người này đều thuộc ngữ hệ Nam Á và phân bố ở nam Tây Nguyên. Do sự phát triển dân số, các bộ tộc nói ngôn ngữ Nam Đảo từ phía biển với sự phát triển của văn hoá tiền $\mathrm{Sa}$ Huỳnh và $\mathrm{Sa}$ Huỳnh bắt đầu chuyển cư lên miền núi. Nhóm này đã chia tách cư dân nói các ngôn ngữ Bahnar Bắc ở khu vực Bắc Tây Nguyên với cư dân nói ngôn ngữ Bahnar Nam ở Đắk Lắk, Đắk Nông và Lâm Đồng. Cuộc tiếp xúc này có thể diễn ra vào khoảng 3,500BP (Đoàn, 2012; Nguyễn \& Đoàn, 2014, tr. 71-79). Lớp cư dân mới này đã chiếm một phần cao nguyên Kon Tum, toàn bộ các cao nguyên Pleiku, Đắk Lắk đến sát vùng 
biên giới Việt - Lào và đẩy một bộ phận cư dân nói ngôn ngữ tiểu chi Bahnar (người Bahnar, Xê đăng...) lên phía bắc, đông bắc tới tận cao nguyên An Khê và đông Tây Nguyên. Cũng chính cư dân nói ngôn ngữ Nam Đảo này đã tách một bộ phận những người nói ngôn ngữ tiểu chi Bahnar xuống phía nam để chiếm cứ cao nguyên Đắk Lắk, rồi đẩy dần họ về phía nam tới Đắk Nông, Lâm Đồng ngày nay (Đoàn, 2012).

Một tư liệu khảo cổ khác cũng rất đáng chú ý là gốm văn thừng xuất hiện sớm trong di chỉ Biển Hồ, Lung Leng đã gợi ý là người Nam Đảo đến Bắc Tây Nguyên sau người nói ngôn ngữ Môn-Khmer. Loại hoa văn gốm in ấn mép miệng vỏ sò, văn in hình răng sói chỉ gặp ở vùng biển, lớp trên di tích Biển Hồ, Trà Dôm, và Lung Leng không xuất hiện ở Nam Tây Nguyên như Lâm Đồng, Đắk Nông cũng gợi ý về sự tiếp xúc của cư dân biển với cao nguyên diễn ra sau khi văn hóa của người chế tác và sử dụng rìu có vai được xác lập ở Gia Lai và Kon Tum.

Tựu chung, cư dân tiền sử Tây Nguyên là kết quả tiếp xúc giữa các nhóm cư dân tại chỗ. Những người nói ngôn ngữ Nam Á đến trước so với cư dân nói ngôn ngữ Nam Đảo đến sau, vào khoảng 4,000BP. Sau đó, một bộ phận lan tỏa lên phía bắc tiếp cận với người nói ngôn ngữ Môn-Khmer thuộc nhóm Bahnar Bắc và rất có thể đã tạo dựng nên văn hóa Lung Leng. Một bộ phận khác di cư xuống phía nam, tiếp xúc với nhóm Bahnar Nam, tạo dựng văn hóa Buôn Triết. Nhóm Jrai Hdrung cư trú quanh thành phố Pleiku và cao nguyên Pleiku, về cơ bản là trùng khớp với phạm vi phân bố của văn hoá Biển Hồ. Một bộ phận khác có thể là người Jrai di cư xuống phía nam, về cơ bản nhóm Jrai Chor cư trú ở vùng đồng bằng thung lũng sông $\mathrm{Ba}$, sông Ayun, các huyện Chư Sê, Chư Pưh (Gia Lai), Ea Kar, Ea H’leo, Ea Súp (Đắk Lắk), nơi phân bố các di tích khảo cổ thuộc văn hoá Taipêr. Thông qua nghiên cứu tư liệu và khảo sát các sưu tập di vật trong các văn hóa khảo cổ tác giả đồng ý về những giả thuyết về chủ nhân của các văn hóa khảo cổ ở Tây Nguyên như đã trình bày ở trên. Chúng tôi sẽ trở lại vấn đề này khi có những nghiên cứu mới với nhiều nguồn tư liệu, nhiều phương pháp tiếp cận khác nhau trong đó có ngôn ngữ tộc người, khảo cổ - nhân học so sánh, nghiên cứu khai quật để có thể phác thảo một cách chuẩn xác nhất về chủ nhân các văn hoá khảo cổ trong tiền sử ở Tây Nguyên. Đặc biệt, những tư liệu nghiên cứu về di cốt người trong hang động núi lửa ở Krông Nô mà chúng tôi đang chỉnh lý sẽ soi sáng vấn đề này trong tương lai.

\section{KẾT LUẬN}

Đến nay, ở Tây Nguyên đã phát hiện và nghiên cứu gần 200 di tích thuộc giai đoạn Đá mới muộn. Trong đó, một số các di tích thuộc phạm trù của ba văn hóa khảo cổ, như: Biển Hồ, Lung Leng, và Buôn Triết. Với các di tích công xưởng thì hình thành một số trung tâm, như: Trung tâm Ia Mơr - Làng Krông; Chư K'tur - Taipêr; H'lang và trung tâm Thôn Bốn - Hoàn Kiếm đã gợi mở khả năng xác lập mới các văn hoá khảo cổ ở Tây Nguyên. Có thể nói, những tác động của hoạt động trong công xưởng đã làm thay đổi cơ cấu kinh tế của người nguyên thuỷ cũng như trong giao lưu trao đổi sản phẩm từ công xưởng. Thông qua tư liệu và bức tranh ngôn ngữ tộc người, các nhà nghiên cứu đã đưa ra giả thuyết về chủ nhân của các văn hóa khảo cổ hay nhóm các di tích ở Tây Nguyên. Trong tình hình tư liệu hiện nay, bài viết đồng quan điểm với các tư liệu 
dẫn trên. Tuy nhiên, vấn đề này cần tiếp tục nghiên cứu trong tương lai để có thể tìm ra mối liên hệ với các cư dân tại chỗ ở Tây Nguyên hiện nay và bức tranh thống nhất trong đa dạng của văn hoá tiền sử Tây Nguyên. Cũng theo đó, có thể rút ra vài kết luận cơ bản sau:

- Hoạt động thủ công chế tác rìu bôn đá giai đoạn Đá mới muộn ở Tây Nguyên đã trải qua các công đoạn: Khai thác nguyên liệu, ghè đẽo tạo ra các phác vật rìu hoặc bôn, tiếp tục ghè tu chỉnh và mài hoàn thiện. Đây là một hoạt động sản xuất trong xã hội tiền sử tạo ra sản phẩm đáp ứng nhu cầu của xã hội. Các hoạt động chế tác đã thể hiện trình độ kỹ thuật trong sản xuất, trình độ tổ chức sản xuất mang tính đặc thù của mỗi cộng đồng người, cũng như những tác động của hoạt động này đối với sự phát triển kinh tế xã hội thời tiền sử ở Tây Nguyên;

- Trong hệ thống các công xưởng giai đoạn Đá mới muộn ở Tây Nguyên đã xuất hiện đồng thời các di tích công xưởng, di tích cư trú - xưởng và di tích cư trú - xưởng - mộ táng. Loại hình các công xưởng này có quy mô tương đối lớn, có sự chuyên hóa nhất định ở mỗi trung tâm cả về nguyên liệu, loại hình công cụ và kỹ thuật chế tác. Rìu bôn có vai và rìu bôn tứ giác làm từ đá opal, loại bôn răng trâu làm từ đá phtanit là sản phẩm chính của các trung tâm hay các nhóm công xưởng khác nhau;

- OỎ Tây Nguyên, các di tích chuyên chế tạo rìu hình bầu dục, nạo hình đĩa, rìu ngắn bằng đá basalte gợi lại kỹ thuật Hòa Bình muộn, niên đại Đá mới sớm cổ hơn và không thuộc hệ thống các công xưởng Đá mới muộn ở Tây Nguyên. Về niên đại, những công xưởng chế tác rìu bôn có vai hay rìu, bôn tứ giác bằng đá opal có niên đại khoảng 4,000 - 3,000BP, các công xưởng chế tác bôn hình răng trâu bằng đá phtanit có tuổi muộn hơn, khoảng 3,500 - 2,500BP. Tài liệu địa tầng, loại hình học công cụ và niên đại Carbon phóng xạ (C14) trong một số di tích công xưởng ở Tây Nguyên đã ủng hộ quan điểm trên;

- Trong giai đoạn Đá mới muộn ở Tây Nguyên đồng loạt ra đời các nhóm hoặc các trung tâm công xưởng chế tác công cụ đá với những sắc thái riêng, mang tính tiểu vùng. Mỗi trung tâm lại có các địa điểm, các địa điểm ây đảm nhận sự chuyên hoá theo từng công đoạn chế tác công cụ. Việc phân công lao động này đã vượt ra khỏi bộ tộc, vươn tới các bộ tộc liền kề. Đây là các yếu tố tích cực, có tác động đến sự phát triển sản xuất. Và quan trọng hơn, tạo nên sự thống nhất trong đa dạng về văn hoá của các cộng đồng cư dân tiền sử ở Tây Nguyên;

- Nghiên cứu hệ thống các di tích công xưởng chế tác công cụ đá ở Tây Nguyên có giá trị đặc biệt trong nhận thức văn hoá, lịch sử một vùng đất, xem xét trình độ kỹ thuật, khả năng sáng tạo văn hoá của từng cộng đồng cư dân cổ, giá trị sản phẩm làm ra được giao lưu, trao đổi giữa các cộng đồng cư dân với nhau. Không chỉ thế, giữa các di tích công xưởng gắn 
với nhau thành cụm di tích kiểu "liên xưởng" trong một kết cấu chung của các bộ tộc giai đoạn Đá mới muộn Tây Nguyên;

- Sự xuất hiện của các công xưởng chế tác rìu, bôn đá - một công cụ bổ trợ cho kinh tế nông nghiệp trồng trọt nương rẫy, nông nghiệp dùng cuốc. Các di tích công xưởng chế tác công cụ đá ở Tây Nguyên cho thấy tính đặc thù của hoạt động chế tác công cụ. Cùng một lúc xuất hiện các hoạt động chế tác ở nhiều nơi, nhiều loại hình sản phẩm, nhiều loại chất liệu khác nhau. Trong mỗi nhóm cư dân ở một địa hình nhất định lại chế tác ra một hoặc hai loại hình công cụ để sử dụng và trao đổi giữa các nhóm cư dân. Sự xuất hiện các công xưởng chuyên hoá chế tác rìu, bôn đá đã làm cho các địa phương có sự khác biệt về loại hình công cụ. Những loại hình công cụ đặc trưng ây đã in đậm lên nội hàm của các văn hoá hoặc các nhóm di tích hiện biết ở Tây Nguyên.

Bằng phân tích so sánh các di tích công xưởng chế tác rìu và bôn đá ở Tây Nguyên với các di tích công xưởng đồng đại ở miền Bắc, miền Trung và miền Nam Việt Nam, tác giả đã xác định tính đặc thù rõ rệt của loại hình công xưởng chế tác công cụ rìu và bôn đá ở Tây Nguyên, cũng như vị trí của chúng trong tiển trình phát triển tiền sử ở Tây Nguyên, miền Trung, Nam bộ Việt Nam và cả bán đảo Đông Dương nữa.

\section{TÀI LIỆ THAM KHẢO}

Đặng, N. V., \& Cẩm, T. (1981). Các dân tộc tỉnh Gia Lai - Kon Tum. Hà Nội, Việt Nam: NXB. Khoa học Xã hội.

Đoàn, V. P. (2012). Ngôn ngũ tộc người và vấn đề chủ nhân các nền văn hóa tiền sủ Miền Trung - Tây Nguyên. Hà Nội, Việt Nam: Viện Khảo cổ học.

Geldern, H. R. (1932). Urheimat und früheste Wanderungen der Austronesier. Anthropos, 27(3-4), 543-619.

Hà, V. T. (1998). Khảo cổ học Việt Nam (Tập 1). Hà Nội, Việt Nam: NXB. Đại học Quốc gia Hà Nội.

Hoàng, X. C. (2004). Phác thảo tiến trình văn hóa khảo cổ Tây Nguyên trong không gian và thời gian. Tạp chí Khảo cổ học, (3), 9-16.

Lafont, B. P. (1956). Note sur un site néolithique la province Pleiku. BEFEO, 38(1), 233-248.

Lê, H. Đ., \& Nguyễn, G. Đ. (2008). Nhận thức về thời đại Đá mới ở Tây Nguyên qua khai quật di chỉ Thôn Tám. Tạp chí Khảo cổ học, (1), 18-29.

Lê, X. H. (2011). Các di tích công xưởng ở Lâm Đồng: Tư liệu và nhận thức. Tạp chí Khảo cổ học, (6), 12-22.

Lê, X. H. (2013). Các công xương chế tác công cu đá giai đoạn hậu kỳ đá mới ở tỉnh Đắk Nông. Lâm Đồng, Việt Nam: Trường Đại học Đà Lạt. 
Lê, X. H., \& Phan, T. T. (2013). Khảo cổ học lòng hồ Plêi Krông trong phối cảnh tiền sử Duyên hải Nam Trung Bộ. Tạp chí Khoa học Xã hội Miền Trung, (6), 48-56.

Lê, X. H., \& Phan, T. T. (2014). Phát hiện mới di chỉ - xưởng chế tác công cụ đá Suối Bốn (Đắk Nông). Trong Nhũng phát hiện mới về Khảo cổ học năm 2013 (tr. 137-139). Hà Nội, Việt Nam: NXB. Khoa học Xã hội.

Lê, X. H. (2015). Các di tích công xuơong chế tác công cu đá giai đoạn hậu kỳ Đá mói so kỳ Đồng thau ở Tây Nguyên. (Luận án Tiển sĩ), Học viện Khoa học Xã hội, Việt Nam.

Lê, X. H., La, T. P., Phạm, T. P. T., Vũ, T. Đ., \& Nguyễn, T. M. (2018). Tư liệu và nhận thức bước đầu về cuộc thám sát di tích hang động núi lửa C6-1 ở Krông Nô, tỉnh Đắk Nông. Tạp chí Khoa học Đại học Đà Lạt, 8(4), 57-76.

Lê, Đ. P., \& Nguyễn, K. S. (2006). Khảo cổ học Tiền sủ - So sủ Miền Trung - Tây Nguyên. Thừa Thiên Huế, Việt Nam: NXB. Đại học Huế.

Nguyễn, G. Đ., \& Lê, H. Đ. (2007). Di chỉ xưởng Chư K'tu và hệ thống công xưởng chế tác đá opal ở Tây Nguyên. Tạp chí Khảo cổ học, (1), 15-25.

Nguyễn, G. Đ., Lê, H. Đ., Ngô. T. K. C., \& Hoàng, T. N. (2008). Về sưu tập hiện vật của Nguyễn Thế Vinh (Đắk Nông). Trong Nhũng phát hiện mới về Khảo cổ học năm 2007 (tr. 70-72). Hà Nội, Việt Nam: NXB. Từ điển Bách khoa.

Nguyễn, K. S. (1995). Văn hóa Biển Hồ ở Tây Nguyên. Tạp chí Khảo cổ học, (3), 7-16.

Nguyễn, K. S. (2002). Khảo cổ học tiền sử Tây Nguyên và miền Đông Nam Bộ - những mối liên hệ. Thông báo Khoa học Bảo tàng Lịch sủ Việt Nam, (5), 7-17.

Nguyễn, K. S. (2003). Khảo cổ học Tiền sử Tây Nguyên dưới ánh sáng của tài liệu mới. Tạp chí Khoa họ Xã hội Việt Nam, (1), 103-112.

Nguyen, K. S. (2004), The Neolithic cultures of Vietnam. Southeast Asia from prehistory to history. New York, USA: Routledge Curzon.

Nguyễn, K. S. (2004a). Ghi chú thêm về khảo cổ học tiền sử Tây Nguyên. Tạp chí Khảo cổ hoc, (3), 24-34.

Nguyễn, K. S. (2004b). Buôn Ma Thuật lịch sủ hình thành và phát triển. Đắk Lắk, Việt Nam: Sở Văn hóa, Thể thao \& Du lịch tỉnh Đắk Lắk.

Nguyễn, K. S. (2005). Di chỉ Lung Leng, nhận thức bước đầu. Tạp chí Khảo cổ học, (5), 3-14.

Nguyễn, K. S. (2006). Các loại hình cuốc đá với vấn đề nông nghiệp Tiền sử Tây Nguyên. Tạp chí Khảo cổ học, (3), 9-21.

Nguyễn, K. S. (2007a). Khảo cổ học Tiền sủ Tây Nguyên. Hà Nội, Việt Nam: NXB. Giáo dục.

Nguyễn, K. S. (2007b). Khảo cổ học Tiền sủ Kon Tum. Hà Nội, Việt Nam: NXB. Khoa học Xã hội. 
Nguyễn, K. S., \& Phan, T. T. (2007). Khai quật di chỉ xưởng Taipêr (Gia Lai), tư liệu, nhận thức và thảo luận. Tạp chí Khảo cổ học, (5), 18-30.

Nguyễn, K. S., Nguyễn, T. Đ., \& Lê, H. Đ. (2008). Báo cáo khai quật di chỉ Ia Morr, xã Ia Mo, huyện Chu Prông (Gia Lai). Hà Nội, Việt Nam: Viện Khảo cổ học.

Nguyễn, K. S. (2009). Các di tích công xưởng Tây Nguyên với khảo cổ học lý thuyết. Tạp chí Khảo cổ học, (2), 3-14.

Nguyễn, K. S. (2010). Văn hóa Sa Huỳnh - Văn hóa Lung Leng, những mối liên hệ. Tạp chí Khoa học Xã hội Miền Trung, (1), 35-45.

Nguyễn, K. S. (2013a). Chỉnh lý, nghiên cứu, bảo quản, phục chế di tích và di vật sau khai quật vùng lòng hồ thủy điện Plei Krông (Kon Tum) (Đề tài nghiên cứu Khoa học cấp Bộ). Hà Nội, Việt Nam: Viện Khảo cổ học.

Nguyễn, K. S. (2013b). Nghiên cưu, đánh giá giá trị lịch sủ văn hóa Việt Nam qua các di tích thời tiền sử ở miền Trung và Tây Nguyên được phát hiện tù̀ 1998 đến 2010 (Đề tài nghiên cứu Khoa học cấp Bộ). Hà Nội, Việt Nam: Viện Khảo cổ học.

Nguyễn, K. S. (2014). Dấu ấn văn hoá tiền - sơ sủ vùng lòng hồ Plei Krông, Kon Tum. Hà Nội, Việt Nam: NXB. Khoa học Xã hội.

Nguyễn, K. S., \& Đoàn, V. P. (2014). Giả thuyết về chủ nhân các di tích văn hoá Đá mới muộn ở Tây Nguyên. Tạp chí Khảo cổ học, (6), 71-79.

Nguyễn, T. K. V. (2004). Dấu ấn văn hóa Biển Hồ trong tộc người Jrai ở Gia Lai Kon Tum. Trong Một thế kỷ khảo cổ học Việt Nam (Tập 1). Hà Nội, Việt Nam: NXB. Khoa học Xã hội.

Nguyễn, M. T. (2015). Báo cáo so bộ kết quả khai quật khảo cổ học di tích Buôn Kiều (xã Yang Mao, huyện Krông Bông, tỉnh Đắk Lắk). Hà Nội, Việt Nam: Bảo tàng Lịch sử Quốc gia.

Phan, T. T. (2015). Hệ thống các di chỉ xưởng chế tác rìu đá ở thượng du sông Ba. Tạp chí Khảo cổ học, (1), 48-59.

Trần, V. B., \& Lê, X. H. (2014). Kết quả điều tra, thám sát di chỉ khảo cổ học Suối Ba (Đắk Nông). Trong Nhũng phát hiện mới về Khảo cổ học năm 2013 (tr. 134137). Hà Nội, Việt Nam: NXB. Khoa học Xã hội.

Trần, V. B. (2014). Khảo cổ học Tiền - sơ sủ và Lịch sủ Lâm Đồng. Hà Nội, Việt Nam: NXB. Khoa học Xã hội.

Trần, Q. T. (2001). Hậu kỳ Đá mới - sơ kỳ kim khí Tây Nguyên. (Luận án Tiến sĩ), Viện Khảo cổ học, Việt Nam.

Vũ, N. B. (1995). Tiền sủ Gia Lai. Hà Nội, Việt Nam: NXB. Văn hóa Thông tin. 